\title{
Grain size and mineralogical indicators of weathering in the Oberlaab loess-paleosol sequence, Upper Austria
}

\author{
Franz Ottner, Sergey Sedov, Undrakh-Od Baatar, Karin Wriessnig
}

How to cite:

Ottner, F., Sedov, S., BaAtar, U., Wriessnig, K. (2013): Grain size and mineralogical indicators of weathering in the Oberlaab loess-paleosol sequence, Upper Austria. - E\&G Quaternary Science Journal, 62 (1): 34-43. DOI: 10.3285/eg.62.1.04

Abstract:

Grain size analyses, bulk and clay mineralogical data were used to characterize weathering within the loess-paleosol-sequence of Oberlaab in Upper Austria. Soil horizons can be clearly identified by the calculation of weathering index Kd from granulometric parameters.

The mineralogical composition of the bulk samples shows increasing weathering intensity from the top to the bottom. The weakest weathering stage 1 is not present in Oberlaab, because all samples are free of carbonate minerals. Weathering stage 2 can be found in the upper part of the profile, whereas stage 3 is mainly present in the lowermost horizons. The highest weathering stages 4 and 5 are not present in Oberlaab. The clay mineral distribution in the profile is dominated by the disappearance of primary chlorite in the upper part of the profile and the neoformation of vermiculites from illite by pedogenesis in the lower part.

Two different types of mixed layer minerals were found in the pedocomplexes. An illite/chlorite mixed layer mineral occurs following the disappearance of chlorite and is present in the Eemian luvisol. The second mixed layer mineral consists of illite/vermiculite and is present in the whole profile.

The weathering stages obtained from the clay mineral composition are slightly lower than that of bulk mineralogy, but reach as well stage 3 in the lower part of the profile.

Korngrößen und mineralogische Verwitterungsintensitäten in der Löss-Paläoboden-Sequenz von Oberlaab, Oberösterreich

Kurzfassung: $\quad$ Untersuchungendes Gesamt-und Tonmineralbestandes sowie der Korngröße wurden zurCharakterisierung derVerwitterungsstadien in einer Löss-Paläoboden-Sequenz in Oberlaab(Oberösterreich) verwendet. Durch den aus der Korngrößenzusammensetzung berechneten Verwitterungsindex Kd können Bodenhorizonte eindeutig identifiziert werden.

Der Gesamtmineralbestand zeigt, dass die Verwitterungsintensität mit der Tiefe zunimmt. Das schwächste Verwitterungsstadium tritt in Oberlaab nicht auf, da alle Proben karbonatfrei sind. Verwitterungsstadium 2 kommt in den oberen Bodenhorizonten vor und ist durch das Fehlen von primärem Chlorit in der Tonfraktion gekennzeichnet. Die untersten Horizonte entsprechen mit der Neubildung von Vermikuliten aus Illit Verwitterungsstadium 3. Die intensivsten Verwitterungsstadien 4 und 5 treten in diesem Profil nicht auf.

In den Pedokomplexen wurden zwei verschiedene Mixed-layer-Minerale gefunden. Ein Illit-Chlorit-Mixed layer kommt in der Parabraunerde des Eem-Interglazials vor, ein Illit-Vermikulit-Mixed layer ist im gesamten Profil nachweisbar.

Die aus der Zusammensetzung der Tonfraktion ermittelten Verwitterungsstadien sind etwas niedriger als die aus dem Gesamtmineralbestand, erreichen aber im untersten Teil des Profils ebenfalls Stufe 3.

Key words:

Paleosols, clay minerals, vermiculite, secondary chlorite, weathering index Kd

Addresses of authors: Franz Ottner, Undrakh-Od Baatar, Karin Wriessnig, Institute of Applied Geology, Department of Civil Engineering and Natural Hazards, University of Natural Resources and Life Sciences Vienna, Peter Jordan Strasse 70, 1190 Wien, Austria; Sergey Sedov, Instituto de Geología, Universidad nacional Autónoma de México (UNAM), Ciudad Universitaría, Del. Coyoacán, C.P. 04510, DF Mexico.

\section{Introduction}

The weathering status of Pleistocene loessic paleosols provides an important proxy for interglacial paleoenvironments as the processes of primary mineral breakdown and neoformation of secondary components are strongly dependent upon the bioclimatic conditions of pedogenesis, (TERHORST, 2013, this volume). Geochemical indicators (various coefficients based on ratios of different major and trace element concentrations) are widely used to evaluate weathering (Buggle et al., 2011). For the Oberlaab sequence this approach was applied by Solleiro-ReBolledo et al. (2013, this volume). Paleomagnetic stratigraphy of the Middle to Upper Pleistocene loess/paleosol sequence of Wels-Aschet is presented by SCHOLGER \& TERHORST (2013, this volume). A detailed overview, as geographical position and geology of Oberlaab as well as the detailed profile description can be found in TERHORST (2013, this volume).

An important additional set of weathering indicators is related to the grain size distribution and mineralogical composition of total soil samples and clay fraction. The products of pedogenic silicate alteration are concentrated mostly in 
the fine material. This justifies to use the ratios of different size fractions as an estimate of this process. PÉcsi $\mho \mathrm{RICH}^{-}$ TER (1996) proposed the weathering index Kd as an integral measure of weathering intensity in paleosols and pedocomplexes. Additional information can be obtained from the proportion of the clay fraction and specifically of the fine clay fraction. The latter consists mostly of products of more advanced transformation and synthesis of secondary minerals, whereas coarse clay is produced mostly from physical breakdown accompanied by moderate chemical transformation (CHAMLEy, 1989).

The mineralogical composition of total soil samples (although only semi-quantitative) provides hints to estimate the weathering status, through the relative abundance of weatherable components (e.g. chlorite, amphiboles, etc.) and stable minerals (especially quartz). Clay mineral assemblages are sensitive indicators of paleopedogenesis and paleoenvironments. The formation of different clay minerals in modern soils is highly dependent upon the soil processes and regimes, which in turn are controlled by climatic conditions (DIXON \& WEED, 1989). Clay mineral studies in loess-paleosol sequences thus provide important proxies for the Pleistocene climatic history (Bronger \& HeIn Kele, 1990; Bronger et al., 1998).

The aim of this study is to estimate the weathering status of the Pleistocene paleosols in the Oberlaab loess profile using grain size, bulk mineralogy and clay mineral assemblages. We further compare these data with other proxies available for this profile to incorporate them into the integral paleoecological interpretation.

\section{Methodology}

\subsection{Grain size distribution}

The grain size distribution was determined by combination of wet sieving of the fraction $>20 \mu \mathrm{m}$ and automatic sedimentation analysis with a Micromeritics SEDIGRAPH III 5120.

$50 \mathrm{~g}$ of the dried sample were treated with $200 \mathrm{ml} 10 \%$ $\mathrm{H}_{2} \mathrm{O}_{2}$. The purpose was the oxidation of organic components and a proper dispersion of the sample. After approximately 24 hours reaction time the unused $\mathrm{H}_{2} \mathrm{O}_{2}$ was removed by heating. After ultrasonic treatment the sample was sieved with a set of $2 \mathrm{~mm}, 630 \mu \mathrm{m}, 200 \mu \mathrm{m}, 63 \mu \mathrm{m}$ and $20 \mu \mathrm{m}$ sieves. The coarse fractions were dried at $105^{\circ} \mathrm{C}$ and stated in mass percent. The $<20 \mu \mathrm{m}$ portion was treated with $0.05 \%$ sodium polyphosphate and analyzed in the sedigraph by X-rays, according to Stoke's Law. From the cumulative curve of the sedigraph and the sieving data the grain size distribution of the entire sample was calculated.

A general overview of the grain size distribution in Oberlaab is presented by Solleiro-REBolledo et al. (2013). In this paper we present mostly the data relevant for the evaluation of the soil weathering index Kd. Silt $(2-63 \mu \mathrm{m})$ including coarse silt $(20-63 \mu \mathrm{m})$ and clay $(<2 \mu \mathrm{m})$ including fine clay $(<0.2 \mu \mathrm{m})$ fractions are evaluated.

\subsection{Total mineral analysis}

The dried samples, ground in a rock mill to analytical size, were prepared according to the backloading method and Xrayed with a Panalytical XPert Pro MPD diffractometer with an automatic divergence slit, $\mathrm{Cu}$ LFF tube, $45 \mathrm{kV}, 40 \mathrm{~mA}$, and an $\mathrm{X}^{\prime}$ Celerator detector. The samples were measured from $2^{\circ}$ to $70^{\circ} 2 \Theta$. The X-ray diffraction patterns served as the basis for calculating the qualitative mineral content.

\subsection{Clay mineral analysis}

The samples were dispersed with $10 \%$ hydrogen peroxide. After the reaction had subsided and the extra $\mathrm{H}_{2} \mathrm{O}_{2}$ was removed, they were exposed to ultrasonic sounding for 15 minutes. The $<63 \mu \mathrm{m}$ fraction was obtained by wet sieving, and out of this the $2 \mu \mathrm{m}$ fraction by centrifugation.

The next step was cation exchange. $40 \mathrm{ml}$ of the clay suspension were each mixed with $10 \mathrm{ml} 4 \mathrm{~N} \mathrm{KCl}$ solution and $4 \mathrm{~N} \mathrm{MgCl}_{2}$ solution, respectively, and shaken for 12 hours. The texture specimens were placed on ceramic platelets, onto which the clay suspension was sucked via low pressure.

After treatment with ethylene glycol, DMSO (dimethyl sulfoxide) and heating 2 hours at $550{ }^{\circ} \mathrm{C}$ the samples were measured in the diffractometer and evaluated according to the same principle as the total mineral analysis. In general, the identification of the minerals and clay minerals was carried out according to BRINDLEY $\mho$ BROWN (1980) and MOORE \& REYNOLDS (1997).

\subsection{Weathering intensity}

In the context of this study, the data collected from the total as well as the clay mineral analysis serve as a basis for estimation of the weathering intensity of the individual horizons. It is assumed that the most sensitive minerals, such as carbonates and chlorite, will be dissolved or replaced first, and, along with increasing weathering, the more stable minerals, such as mica and feldspars.

This method was used for the first time in the loess paleosol profile Wels-Aschet (TerHorst et al., 2012) and slightly modified for the Oberlaab profile (Tables 1 and 2).

Based on the clay mineral analysis, a classification of the weathering intensity was carried out with the presence of primary chlorite on the one hand, and vermiculite varieties on the other hand TERHORST et al. (2012).

\section{Results and discussion \\ 3.1 Grain size analyses of silt and clay}

The variation in clay content $(<2 \mu \mathrm{m})$ is relatively high. The lowest clay content was found in a loess sample of OL4 with 22.7 mass\%, the highest amount of clay was found in clay cutans from the same OL4 profile and is 64.3 mass\% (Table 3). Apart from the clay cutans the highest clay contents occur in the Middle Pleistocene paleosols of profile OL5 (Table 3 and Fig. 1).

The Eemian interglacial Luvisol (OL2) in $120-140 \mathrm{~cm}$ has a very high clay content of 51.3 mass\%, and especially in the deepest part of the profile the clay content is high.

The paleosols of the OL4 profile section are characterized by slightly lower clay contents; only in one sample more than 40 mass $\%$ of the clay fraction were detected. The more recent loess samples of the upper profile sections (OL1) have a clay content of less than 30 mass $\%$. 
Tab. 1: Weathering intensity according to bulk mineralogy after TERHORST et al. (2012).

Tab. 1: Verwitterungsintensität auf der Basis der mineralogischen Ergebnisse nach TERHORST et al. (2012).

\begin{tabular}{|c|c|}
\hline Degree of weathering & Index minerals \\
\hline Stage 1 & Carbonate minerals present \\
\hline Stage 3 & Micas present, chlorite absent \\
\hline Stage 5 & Micas and feldspars absent [weathered] \\
\hline
\end{tabular}

Tab. 2: Weathering intensitiy according to the clay mineralogy, after TERHORST et al. (2012), slightly modified.

Tab. 2: Verwitterungsintensität auf der Basis der tonmineralogischen Ergebnisse nach TERHORST et al. (2012), leicht verändert.

\begin{tabular}{|l|l|l|}
\hline Degree of weathering & Index Minerals \\
\hline Stage 1 & \multirow{5}{*}{ Stage 2} & Primary chlorite present \\
\hline Stage 3 & & Primary chlorite absent, illite or vermiculite $14 \AA$ dominant \\
& & Vermiculite $18 \AA$ dominant, smectite from lessivation dominant \\
\hline Stage 4 & & Vermiculite $18 \AA$ dominant, vermiculite $14 \AA \AA$ completely transformed \\
\hline Stage 5 & & Illite totally weathered \\
\hline
\end{tabular}

The fine clay content $(<0.2 \mu \mathrm{m})$ varies much more than the total clay. The clay cutans from the OL4 profile section contain 54.6 mass\% fine clay, the Eemian paleosol from 120-140 cm (OL2) 31.7 mass\%. In the younger loess samples the value for the fine clay is below 10 mass\%, the lowest value of 3.7 mass\% was found in a loess sample of OL3 (Table 3 and Fig. 2).

As expected, the silt fraction is predominant in most samples and reaches values up to 74.0 mass\% (OL4). By contrast, contents of the silt fraction in the paleosols are significantly lower. In the basal parts of the sequence (OL5), the silt fraction diminishes far below 50 mass\%. The lowest silt value (33.6 mass\%) can be found in the clay cutans of profile section OL4.

The decrease of the silt fraction within the paleosol horizons is significant. This trend is particularly obvious in the Eemian interglacial paleosol (OL2), in which the silt fraction is only 45.6 mass\% (Table 3 ).

Generally speaking, the silt content is higher in the upper part of the profile and lower in the deeper parts because of the known clay enrichment during pedogenesis (Table 3).

\subsection{Kd-values and weathering intensity}

The grain size distribution can be used as an indicator for the degree of weathering. Clay illuviation in Bt horizons causes an enhancement of the fine fraction at the expense of the coarse fraction. The individual soil horizons can be recognized either by the increased values of the clay and fine clay fraction respectively (Figs.1 and 2), or by significantly lower values of the silt and coarse silt fraction.

According to PÉCSI \& RICHTER (1996), the weathering index Kd allows to measure the weathering intensity of pale- osols and pedocomplexes. It is calculated by dividing of the coarse and middle silt content by the fine silt and total clay content. In general, the lower the Kd-value is, the more weathered is the soil horizon (Fig. 3). The lowest Kd-value (0.32), and thus by far the highest degree of weathering, is obtained in the paleosols of profile OL5 and in the clay cutans.

In the Eemian paleosol (OL2) the Kd-value of 0.55 shows that the weathering process - caused by an intensive pedogenesis - is remarkable in this part of the profile as well.

Figure 3 shows clearly the less weathered upper part, a mixed part in the middle and the highly altered deepest part of the OL5 profile section.

Summarizing, paleosols are indicated by the lowest Kdvalues in the studied profile. The enrichment of clay at the expense of the coarse grain fraction can be observed in many samples with low Kd-values.

\subsection{Mineralogical results \\ 3.3.1 Bulk mineral analysis}

All examined samples are free of carbonate (Table 4). Neither the uppermost more recent loess samples nor the samples from the Mindel terrace contain any calcite or dolomite.

Chlorite occurs in higher amounts only in section OL1 and partly in OL2. In OL3 hardly any chlorite is detectable, but traces were present in OL4. In OL5 due to strong weathering processes no chlorite was found (Table 4).

Hornblende - also a mineral relatively sensitive to weathering - could be detected in traces in the profile sections OL1 and OL2, but not in the Eemian paleosol. In older horizons hornblende is not present because of strong weathering (Table 4).

Generally, quartz occurs as a main component throughout the profile in uniform distribution and without recogniz- 


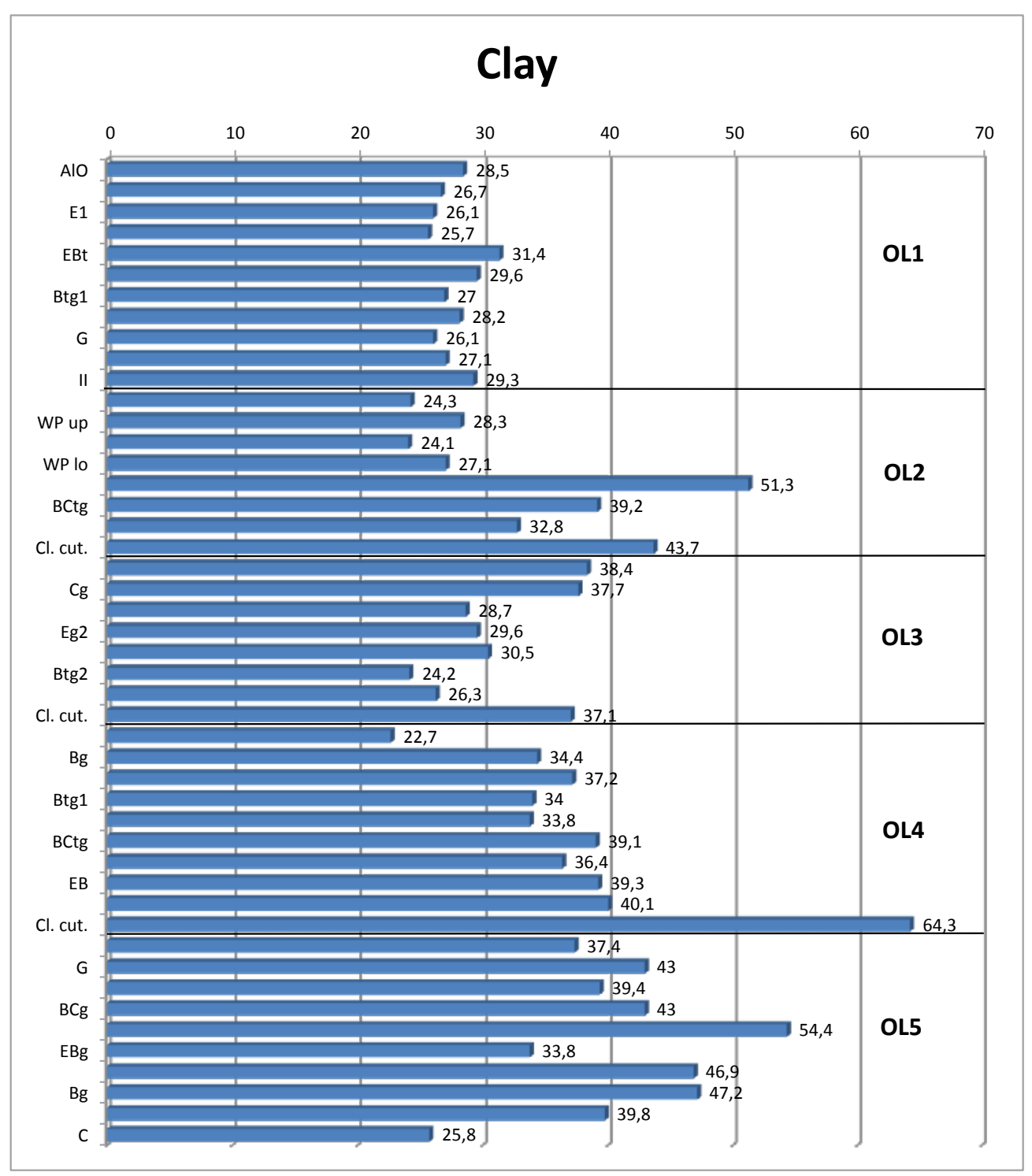

Fig. 1: Total clay content in mass\% in the profile Oberlaab, $W P=$ pedosediments

Abb. 1: Gesamt-Tongehalt im Profil Oberlaab in Masse\%, WP = Bodensedimente.

able trends. Plagioclase is detectable throughout the profile. Potassium feldspar occurs in traces only. In Table 4 the values for both types of feldspars are combined in the column "feldspars".

The distribution of mica is also more or less homogeneous, except for clay cutans, where the amount is higher and in some samples of profile section OL5 it was found only in traces. Layer silicates, which represent the sum of all clay minerals and mica are present in all samples, whereby the highest content can be found in the Bt horizon of the Eemian interglacial paleosol (OL2). The peaks of about $14 \AA$ originate from the clay minerals smectite and vermiculite, which will be discussed in detail in the following chapter.

The total mineral content can be used to estimate the weathering intensity of the individual horizons as based on the presence or absence of indicator minerals (cf. Tab. 1 and 2). Weathering stage 1 represents the horizons with the lowest weathering intensity. In this stage the horizons still contain carbonate minerals. In Oberlaab this stage is not present, as all samples are free of carbonate.

Most horizons can be ascribed to weathering stage 2 . These horizons are characterized by the presence of chlorite with a simultaneous absence of carbonate. All samples from profile section OL1 and OL2, and few samples of section OL3 and OL4 belong to this weathering stage. Only section OL5 is totally free of chlorite.

Weathering stage 3 , in which primary chlorite is absent but mica is still present, comprises the samples from OL 5 and some horizons from OL3 and 4.

The highest weathering stages 4 and 5, which are characterized by the absence of mica and feldspars and by the occurrence of high amounts of layer silicates, are not developed in the Oberlaab profile.

In all horizons, the iron hydroxide goethite could be found in varying amounts.

\subsubsection{Clay mineral analysis}

Clay minerals of the profile show strong dynamics in terms of rearrangement, particularly triggered by vermiculite.

Classical vermiculite, which expands only to $14 \AA$, is present in the lower part of the profile in small amounts with only few exceptions (Table 5). It occurs mainly in the moderately to stronger weathered horizons. The younger profile sections are almost free of vermiculite $14 \AA$.

Advanced weathering leads to the formation of the more strongly expanding vermiculite variety (vermiculite $18 \AA$ ). This mineral is present in intensely weathered horizons, in ad- 


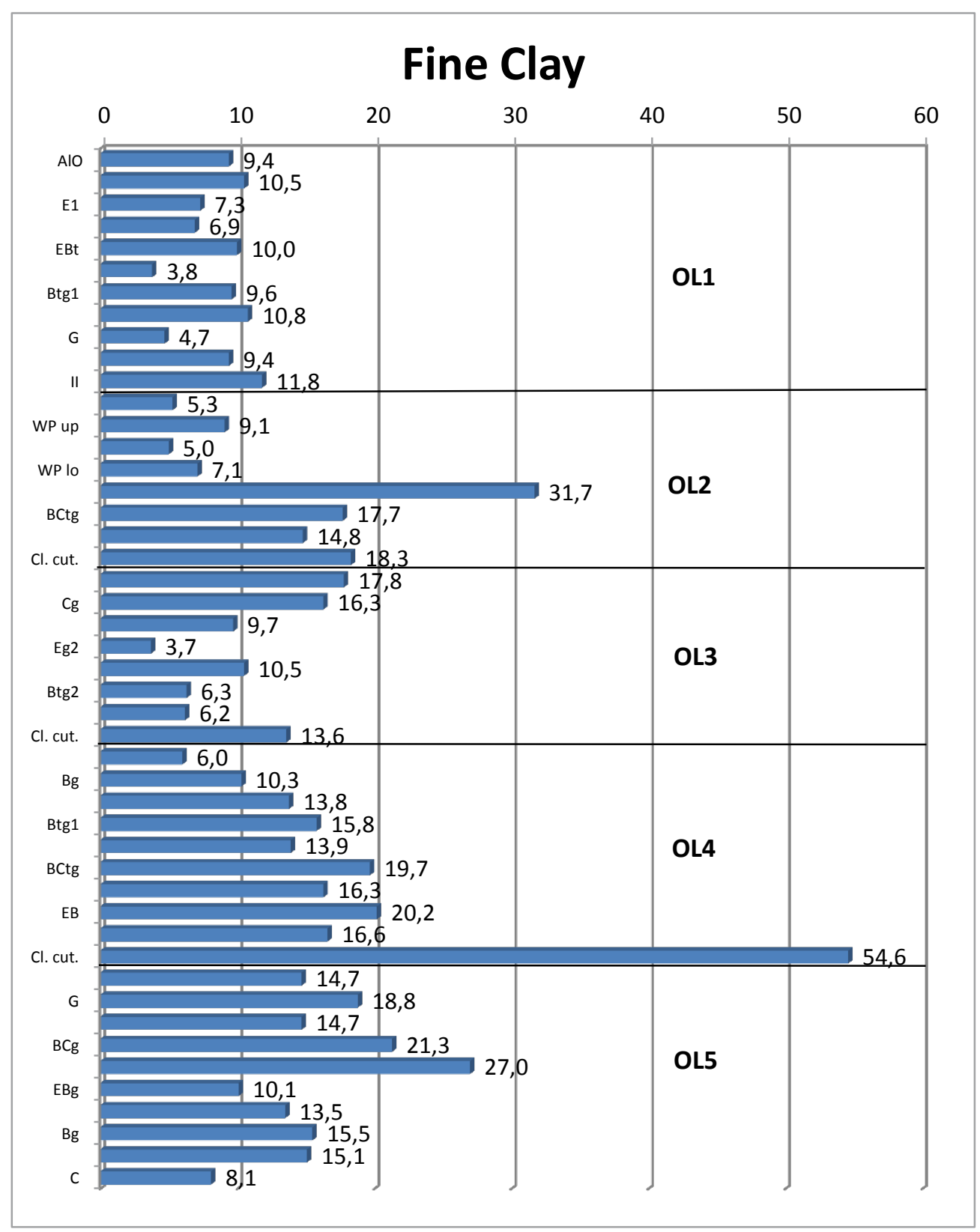

Fig. 2: Fine clay content in mass\% in the profile Oberlaab, $W P=$ pedosediments.

Abb. 2: Feintongehalt im Profil Oberlaab in Masse\%, $W P=$ Bodensedimente.

dition to vermiculite $14 \AA$. In the case of increasing weathering intensity it replaces vermiculite $14 \AA$ completely. In the studied profile it is most frequently present in the older profile sections OL4 and OL5. Smaller amounts are also present in the rest of the profile but without regular distribution or trends.

In all horizons, smectite can also be found in relatively small amounts, in some parts also as a main component of the clay fraction. It is detectable both in soil horizons and in loess sediments. Its occurrence in less weathered loess layers gives reason to believe that smectite was not newly formed within the profile, but rather originates from previously weathered source material. In contrast, the occurrence of the highest amounts of smectite in the Eemian paleosol may originate in neoformation of smectite in those horizons or is caused by lessivation.

The amount of illite, the source material for more weathered clay minerals, does not vary much in the profile, only small amounts are detectable.

Kaolinite can be found in all horizons in small amounts and does not show any recognizable trends. Kaolinite occurs in the well crystallized form expandable with DMSO and in a poorly crystallized form (fire clay).

Primary chlorite occurs occasionally and in small amounts. It is clearly detectable only within the young loess sediments (OL1), while it is absent in all older horizons.

Secondary chlorite, which is found ocassionally in paleosols, is not clearly detectable in the Oberlaab profile.

Most horizons contain two distinguishable mixed layer minerals, which consist of the components illite, chlorite or vermiculite, respectively. The chlorite containing mixed layer mineral occurs mostly in horizons of OL1 following the disappearance of chlorite. It is also present in OL2 and disappears almost completely in the lower horizons. In the clay fractions of all other horizons an additional variety of mixed layer minerals can be found, which is composed of vermiculite and most likely illite (Table 5).

The results from the clay mineral analyses were also classified according to their weathering intensity. This was mainly based on the presence of the vermiculite varieties (Tables 2 and 5). 


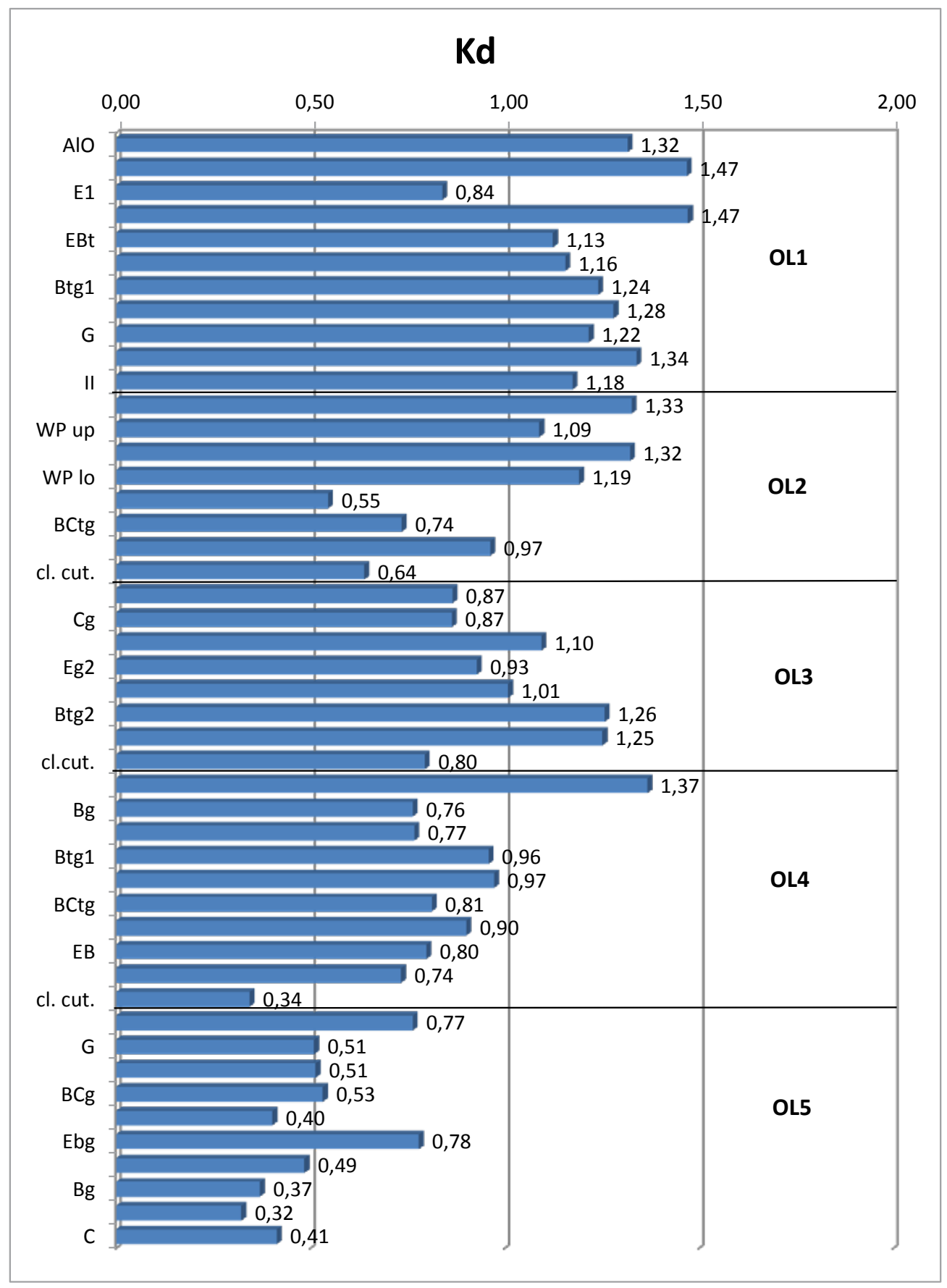

Fig. 3: Distribution of weathering index $K d$ in the profile Oberlaab, $W P=$ pedosediments.

Abb. 3: Verteilung des Verwitterungsindex Kd im Profil Oberlaab, $W P=$ Bodensedimente.

The weakest weathering stage 1 , which is characterized by the presence of primary chlorite, only occurs in the uppermost horizons of OL1. Below that, all horizons are at least at weathering stage 2 , where by definition illite or vermiculite $14 \AA$ are the dominant clay minerals.

Most horizons below OL2 contain higher amounts of vermiculite $18 \AA$, which means they already belong to weathering stage 3. By means of lessivation processes, clay cutans were transported into the larger pores and fissures of the underlying loess loams. This is also reflected by the occurrence of weathering stage 3 .

Weathering stage 4 is only developed in the upper part of the Middle Pleistocene paleosol OL5.

\section{Discussion}

The results show that the paleosol units of Oberlaab are de- veloped as pedocomplexes. The basal parts of the sequence show the highest weathering degree, although the intensity of weathering never reached the highest stages as presented for the nearby loess/paleosol sequence in Wels-Aschet (TerHORST et al., 2012).

Grain size and mineralogical indicators of weathering provide quite similar estimates of the weathering status for the different pedocomplexes of Oberlaab. All these indicators point to the lower weathering grade of the recent Luvisol as compared to all Pleistocene paleosols. The Holocene soil has a lower content of total and fine clay, a higher Kd index, and at the same time demonstrates a lower mineralogical and clay mineralogical weathering stage. The presented results show that the Kd index proposed by PÉcsi \& Richter (1996), fits quite well to the mineralogical weathering stages used in this paper. It is remarkable that among Pleistocene paleosols the most weathered according to grain size characteristics 
Tab. 3: Distribution of silt and clay fractions in the Oberlaab loess-paleosol sequence; mass\%, WP= pedosediments. Tab. 3: Verteilung der Schluff und Tonfraktionen in der Löss-Paläoboden-Sequenz Oberlaab, Masse\%, WP = Bodensedimente.

\begin{tabular}{|c|c|c|c|c|c|}
\hline IAG Lab. Nr & Horizon & Position & Silt & Clay & Fine clay \\
\hline \multicolumn{6}{|c|}{ Profile OL1 Holocene Luvisol } \\
\hline 12401 & AlO & $0-5 \mathrm{~cm}$ & 67.1 & 28.5 & 9.4 \\
\hline 12402 & EAh & $5-15 \mathrm{~cm}$ & 68.9 & 26.7 & 10.5 \\
\hline 11212 & E1 & $15-30 \mathrm{~cm}$ & 71.7 & 26.1 & 7.3 \\
\hline 11213 & E2 & $30-40 \mathrm{~cm}$ & 72.2 & 25.7 & 6.9 \\
\hline 11214 & EBt & $45-65 \mathrm{~cm}$ & 66.2 & 31.4 & 10.0 \\
\hline 11215 & EBtg & $75-95 \mathrm{~cm}$ & 67.7 & 29.6 & 3.8 \\
\hline 11216 & Btg1 & $100-120 \mathrm{~cm}$ & 70.4 & 27.0 & 9.6 \\
\hline 11217 & Btg2 & $140-150 \mathrm{~cm}$ & 69.2 & 28.2 & 10.8 \\
\hline 11218 & G & $150-160 \mathrm{~cm}$ & 70.8 & 26.1 & 4.7 \\
\hline 11219 & I & $150-165 \mathrm{~cm}$ & 70.7 & 27.1 & 9.4 \\
\hline 11220 & $\|$ & $170-190 \mathrm{~cm}$ & 61.5 & 29.3 & 11.8 \\
\hline \multicolumn{6}{|c|}{ Profile OL2 Eemian Luvisol } \\
\hline 11221 & WP upper & $0-20 \mathrm{~cm}$ & 71.6 & 24.3 & 5.3 \\
\hline 11222 & WP upper & $20-40 \mathrm{~cm}$ & 68.1 & 28.3 & 9.1 \\
\hline 11223 & WP lower & $40-50 \mathrm{~cm}$ & 72.0 & 24.1 & 5.0 \\
\hline 11224 & WP lower & $70-90$ & 66.3 & 27.1 & 7.1 \\
\hline 11225 & Btg2 & $120-140 \mathrm{~cm}$ & 45.6 & 51.3 & 31.7 \\
\hline $11226 / 27$ & $\mathrm{BCtg}$ & $160-180 \mathrm{~cm}$ & 58.3 & 39.2 & 17.7 \\
\hline 11228 & BCtg & $180-190 \mathrm{~cm}$ & 64.1 & 32.8 & 14.8 \\
\hline 11229 & clay cutans & & 53.0 & 43.7 & 18.3 \\
\hline \multicolumn{6}{|c|}{ Profile OL3 Middle Pleistocene Paleosol } \\
\hline 11230 & $\mathrm{BCtg}$ & $5-20 \mathrm{~cm}$ & 57.9 & 38.4 & 17.8 \\
\hline 11233 & $\mathrm{Cg}$ & $25-40 \mathrm{~cm}$ & 58.4 & 37.7 & 16.3 \\
\hline 11234 & Eg1 & $40-50 \mathrm{~cm}$ & 64.0 & 28.7 & 9.7 \\
\hline 11235 & Eg2 & $70-90 \mathrm{~cm}$ & 66.7 & 29.6 & 3.7 \\
\hline 11236 & Btg1 & $120-140 \mathrm{~cm}$ & 66.0 & 30.5 & 10.5 \\
\hline 11231 & Btg2 & $180-190 \mathrm{~cm}$ & 70.1 & 24.2 & 6.3 \\
\hline 11232 & $\mathrm{BCg}$ & $210-220 \mathrm{~cm}$ & 70.5 & 26.3 & 6.2 \\
\hline 11238 & clay cutans & & 60.7 & 37.1 & 13.6 \\
\hline \multicolumn{6}{|c|}{ Profile OL4 Middle Pleistocene Paleosol } \\
\hline 11432 & $\mathrm{BCg}$ & $10-30 \mathrm{~cm}$ & 74.0 & 22.7 & 6.0 \\
\hline 11433 & $\mathrm{Bg}$ & $60-70$ & 62.6 & 34.4 & 10.3 \\
\hline 11434 & $\mathrm{Bg}$ & $85-100 \mathrm{~cm}$ & 60.6 & 37.2 & 13.8 \\
\hline 11435 & Btg1 & $120-140 \mathrm{~cm}$ & 63.6 & 34.0 & 15.8 \\
\hline 11436 & Btg2 & $140-150 \mathrm{~cm}$ & 63.9 & 33.8 & 13.6 \\
\hline 11437 & $\mathrm{BCtg}$ & $180-200 \mathrm{~cm}$ & 58.7 & 39.1 & 19.7 \\
\hline 11438 & BCtg & $230-240 \mathrm{~cm}$ & 61.2 & 36.4 & 16.3 \\
\hline 11439 & $\mathrm{~EB}$ & $270-280 \mathrm{~cm}$ & 55.1 & 39.3 & 20.2 \\
\hline 11440 & G & $290-300 \mathrm{~cm}$ & 55.8 & 40.1 & 16.6 \\
\hline 11441 & clay cutans & & 33.6 & 64.3 & 54.6 \\
\hline \multicolumn{6}{|c|}{ Profile OL5 Middle Pleistocene Paleosol } \\
\hline 11442 & BG & $0-50$ & 51.1 & 37.4 & 14.7 \\
\hline 11443 & G & $50-90 \mathrm{~cm}$ & 46.1 & 43.0 & 18.8 \\
\hline 11444 & $\mathrm{Bg}$ & $90-170 \mathrm{~cm}$ & 43.0 & 39.4 & 14.7 \\
\hline 11445 & $\mathrm{BCg}$ & $170-215 \mathrm{~cm}$ & 45.7 & 43.0 & 21.3 \\
\hline 11446 & Ah & $215-230 \mathrm{~cm}$ & 38.8 & 54.4 & 27.0 \\
\hline 11447 & $\mathrm{EBg}$ & $230-250 \mathrm{~cm}$ & 59.0 & 33.8 & 10.1 \\
\hline 11448 & $\mathrm{Bg}$ & $250-260 \mathrm{~cm}$ & 48.1 & 46.9 & 13.5 \\
\hline 11449 & $\mathrm{Bg}$ & $265-290 \mathrm{~cm}$ & 41.9 & 47.2 & 15.5 \\
\hline 11450 & $\mathrm{Cg}$ & $290-310 \mathrm{~cm}$ & 34.6 & 39.8 & 15.1 \\
\hline 11451 & C & $310+$ & 30.9 & 25.8 & 8.1 \\
\hline
\end{tabular}


Tab. 4: Mineral composition of the bulk minerals in the Oberlaab loess-paleosol sequence, $W P=$ pedosediments. Tab. 4: Mineralogische Zusammensetzung der Löss-Paläoboden-Sequenz Oberlaab, WP = Bodensedimente.

\begin{tabular}{|c|c|c|c|c|c|c|c|c|c|c|}
\hline IAG Lab. Nr & & $14 \AA ̊$ & Mica & Chlorite & $\begin{array}{l}\text { Layer sili- } \\
\text { cates }\end{array}$ & Quartz & Feldspar & Hornbl & Calc + Dolo & Weath. stage \\
\hline \multicolumn{11}{|c|}{ Profile OL1 Holocene Luvisol } \\
\hline 12401 & AlO & . & * & * & * & ** & * & . & & 2 \\
\hline 12402 & EAh & . & * & * & * & ** & * & . & & 2 \\
\hline 11212 & E1 & & & * & * & ** & * & . & & 2 \\
\hline 11213 & E2 & . & . & * & * & ** & * & . & & 2 \\
\hline 11214 & $\mathrm{EBt}$ & * & * & * & * & ** & * & & & 2 \\
\hline 11215 & EBtg & * & * & ** & * & ** & * & . & & 2 \\
\hline 11216 & Btg1 & * & * & * & * & ** & * & . & & 2 \\
\hline 11217 & Btg2 & * & * & * & * & ** & * & . & & 2 \\
\hline 11218 & G & * & * & * & * & ** & * & . & & 2 \\
\hline 11219 & 1 & * & * & * & * & ** & * & . & & 2 \\
\hline 11220 & $\|$ & * & * & * & * & ** & * & . & & 2 \\
\hline \multicolumn{11}{|c|}{ Profile OL2 Eemian Luvisol } \\
\hline 11221 & WP upper & * & * & * & * & ** & * & . & & 2 \\
\hline 11222 & WP upper & * & * & . & * & ** & * & & & 2 \\
\hline 11223 & WP lower & * & * & * & * & ** & * & . & & 2 \\
\hline 11224 & WP lower & * & * & * & * & ** & * & & & 2 \\
\hline 11225 & Btg2 & * & * & & ** & ** & * & & & 2 \\
\hline 11226 & BCtg & * & * & & ** & ** & * & & & 2 \\
\hline 11228 & BCtg & ** & * & & ** & ** & * & & & 2 \\
\hline 11229 & clay cut. & * & ** & . & ** & ** & * & & & 2 \\
\hline \multicolumn{11}{|c|}{ Profile OL3 Middle Pleistocene Paleosol } \\
\hline 11230 & BCtg & * & * & & * & ** & * & . & & 2 \\
\hline 11233 & $\mathrm{Cg}$ & ** & * & . & * & ** & * & & & 2 \\
\hline 11234 & Eg1 & * & * & & * & ** & * & & & 3 \\
\hline 11235 & Eg2 & * & * & & * & ** & * & & & 3 \\
\hline 11236 & Btg1 & ** & * & & * & ** & * & & & 3 \\
\hline 11231 & Btg2 & * & * & & * & ** & * & & & 3 \\
\hline 11232 & $\mathrm{BCg}$ & * & * & & * & ** & * & & & 3 \\
\hline 11238 & clay.cut & . & . & . & ** & ** & * & & & 3 \\
\hline \multicolumn{11}{|c|}{ Profile 0L4 Middle Pleistocene Paleosol } \\
\hline 11432 & $\mathrm{BCg}$ & . & * & & * & ** & * & & & 3 \\
\hline 11433 & $\mathrm{Bg}$ & * & * & . & * & ** & * & & & 2 \\
\hline 11434 & $\mathrm{Bg}$ & * & * & . & * & ** & * & & & 2 \\
\hline 11435 & Btg1 & * & * & . & * & ** & * & & & 2 \\
\hline 11436 & Btg2 & ** & * & . & * & ** & * & & & 2 \\
\hline 11437 & BCtg & ** & * & & * & ** & * & & & 2 \\
\hline 11438 & BCtg & ** & * & & * & ** & * & & & 2 \\
\hline 11439 & $\mathrm{~EB}$ & * & * & . & * & ** & * & & & 2 \\
\hline 11440 & G & * & * & & * & ** & * & & & 3 \\
\hline 11441 & Clay cut. & * & * & & ** & * & * & & & 3 \\
\hline \multicolumn{11}{|c|}{ Profile OL5 Middle Pleistocene Paleosol } \\
\hline 11442 & BG & * & * & & ** & ** & * & & & 3 \\
\hline 11443 & G & * & & & ** & ** & * & & & 3 \\
\hline 11444 & $\mathrm{Bg}$ & * & & & ** & ** & * & & & 3 \\
\hline 11445 & $\mathrm{BCg}$ & * & . & & ** & ** & * & & & 3 \\
\hline 11446 & Ah & * & * & & ** & ** & * & & & 3 \\
\hline 11447 & EBg & * & * & & ** & ** & * & & & 3 \\
\hline 11448 & $\mathrm{Bg}$ & * & $*$ & & $* *$ & $* *$ & * & & & 3 \\
\hline 11449 & $\mathrm{Bg}$ & * & * & & ** & ** & * & & & 3 \\
\hline 11450 & $\mathrm{Cg}$ & * & * & & $* *$ & $* *$ & * & & & 3 \\
\hline 11451 & c & * & & & ** & ** & * & & & 3 \\
\hline \multicolumn{11}{|l|}{ Legend: } \\
\hline$* * *$ : mine & arge qu & & & mineral $\mathrm{i}$ & w quantity & & & & & \\
\hline$* *$ : miner & ntermec & quan & & nineral & aces & & & & & \\
\hline
\end{tabular}


Tab. 5: Mineral composition of the clay fraction from the Oberlaab loess-paleosol sequence; well and poorly crystallized kaolinite are together in one column, WP = pedosediments.

Tab. 5: Mineralogische Zusammensetzung der Tonfraktion in der Löss-Paläoboden-Sequenz Oberlaab, WP = Bodensedimente.

\begin{tabular}{|c|c|c|c|c|c|c|c|c|c|c|}
\hline \multirow[b]{2}{*}{ IAG Lab. Nr } & \multirow[b]{2}{*}{ Horizon } & \multirow[b]{2}{*}{ Smectite } & \multirow[b]{2}{*}{ Vermiculite $18 \AA$} & \multirow[b]{2}{*}{ Vermiculite 14Å } & \multirow[b]{2}{*}{ Illite } & \multirow[b]{2}{*}{ Kaolinite } & \multirow[b]{2}{*}{ Chlorite } & \multicolumn{2}{|c|}{ Mixed Layer } & \multirow[b]{2}{*}{ Weath. stage } \\
\hline & & & & & & & & $\mathrm{I} / \mathrm{Vc}$ & l/Chl & \\
\hline \multicolumn{11}{|c|}{ Profile OL1 Holocene Luvisol } \\
\hline 12401 & AlO & & & & * & * & * & $*$ & & 1 \\
\hline 12402 & EAh & & & & * & * & $* *$ & $*$ & & 1 \\
\hline 11212 & E1 & $*$ & $*$ & & $*$ & & $* *$ & $*$ & & 1 \\
\hline 11213 & E2 & $*$ & & & $*$ & $*$ & $* *$ & $*$ & & 1 \\
\hline 11214 & EBt & * & & & $*$ & * & * & $*$ & & 1 \\
\hline 11215 & EBtg & $*$ & & & $*$ & $*$ & $*$ & $*$ & & 1 \\
\hline 11216 & Btg1 & $*$ & & & $*$ & $*$ & . & $*$ & . & 1 \\
\hline 11217 & Btg2 & $*$ & $*$ & & $*$ & * & & * & $*$ & 2 \\
\hline 11218 & G & * & & & * & * & 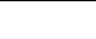 & * & * & 2 \\
\hline 11219 & I & * & & & $*$ & $*$ & . & * & $*$ & 1 \\
\hline 11220 & ॥ & $*$ & & & $*$ & * & & * & . & 2 \\
\hline \multicolumn{11}{|c|}{ Profile OL2 Eemian Luvisol } \\
\hline 11221 & WP upper & $*$ & * & & $*$ & * & & * & $*$ & 2 \\
\hline 11222 & WP upper & $*$ & $*$ & & $*$ & $*$ & & $*$ & . & 2 \\
\hline 11223 & WP lower & $* *$ & & & $*$ & $*$ & & $*$ & . & 2 \\
\hline 11224 & WP lower & $* *$ & & & * & $*$ & & * & . & 2 \\
\hline 11225 & Btg2 & $* * *$ & & & * & * & & * & . & 3 \\
\hline 11226 & $\mathrm{BCtg}$ & $* * *$ & & & $*$ & & & $*$ & . & 3 \\
\hline 11228 & $\mathrm{BCtg}$ & $* * *$ & & & $*$ & . & & $*$ & . & 3 \\
\hline 11229 & clay cut & $* *$ & & & $*$ & * & & . & . & 2 \\
\hline \multicolumn{11}{|c|}{ Profile OL3 Middle Pleistocene Paleosol } \\
\hline 11230 & $\mathrm{BCtg}$ & * & * & * & * & $*$ & & * & . & 3 \\
\hline 11233 & $\mathrm{Cg}$ & * & $*$ & * & $*$ & $*$ & & $*$ & & 3 \\
\hline 11234 & Eg1 & $*$ & $*$ & $*$ & $*$ & $*$ & & * & 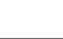 & 3 \\
\hline 11235 & Eg2 & * & * & * & * & * & & * & . & 3 \\
\hline 11236 & Btg1 & * & & & * & * & & * & & 3 \\
\hline 11231 & Btg2 & $*$ & & $*$ & $*$ & $*$ & & $*$ & & 3 \\
\hline 11232 & $\mathrm{BCg}$ & * & $* *$ & & $*$ & $*$ & & $*$ & & 3 \\
\hline 11238 & clay.cut & $*$ & * & $*$ & * & * & & $*$ & & 3 \\
\hline \multicolumn{11}{|c|}{ Profile OL4 Middle Pleistocene Paleosol } \\
\hline 11432 & $\mathrm{BCg}$ & $*$ & $* *$ & * & * & * & & . & & 3 \\
\hline 11433 & $\mathrm{Bg}$ & * & $* *$ & & * & . & & . & & 3 \\
\hline 11434 & $\mathrm{Bg}$ & $*$ & $* *$ & & $*$ & . & & . & & 3 \\
\hline 11435 & Btg1 & $*$ & $* *$ & * & * & * & & . & & 3 \\
\hline 11436 & Btg2 & $*$ & $* *$ & $*$ & $*$ & . & & . & & 3 \\
\hline 11437 & BCtg & * & $* *$ & $*$ & * & * & & . & & 3 \\
\hline 11438 & BCtg & $* *$ & $* *$ & $*$ & * & * & & . & & 3 \\
\hline 11439 & EB & * & $* *$ & . & * & * & & . & & 3 \\
\hline 11440 & G & $*$ & $* *$ & $*$ & $*$ & * & & . & & 3 \\
\hline 11441 & Clay cut. & & $* *$ & $*$ & * & . & & . & . & 3 \\
\hline \multicolumn{11}{|c|}{ Profile OL5 Middle Pleistocene Paleosol } \\
\hline 11442 & BG & $* *$ & $* *$ & & * & * & & . & . & 4 \\
\hline 11443 & G & $* *$ & $* *$ & & $*$ & . & & . & & 4 \\
\hline 11444 & $\mathrm{Bg}$ & $*$ & $* *$ & & . & . & & . & & 4 \\
\hline 11445 & $\mathrm{BCg}$ & * & $* *$ & & $*$ & . & & . & & 4 \\
\hline 11446 & Ah & * & $* *$ & & * & . & & . & & 4 \\
\hline 11447 & $\mathrm{EBg}$ & $*$ & $* *$ & $*$ & $*$ & & & . & & 3 \\
\hline 11448 & $\mathrm{Bg}$ & $* *$ & $* *$ & $*$ & $*$ & & & . & . & 3 \\
\hline 11449 & $\mathrm{Bg}$ & $* *$ & $* *$ & $*$ & * & . & & . & & 3 \\
\hline 11450 & $\mathrm{Cg}$ & $* *$ & $* *$ & * & * & . & & . & & 3 \\
\hline 11451 & C & $* *$ & $* *$ & $*$ & $*$ & & & . & . & 3 \\
\hline Legend: & & & & & & & & & & \\
\hline$* * *: \min$ & in large & & $*: \min$ & eral in low qua & tity & & & & & \\
\hline$* *:$ mine & I in interm & te quar & $\cdot: \min$ & eral in traces & & & & & & \\
\hline
\end{tabular}




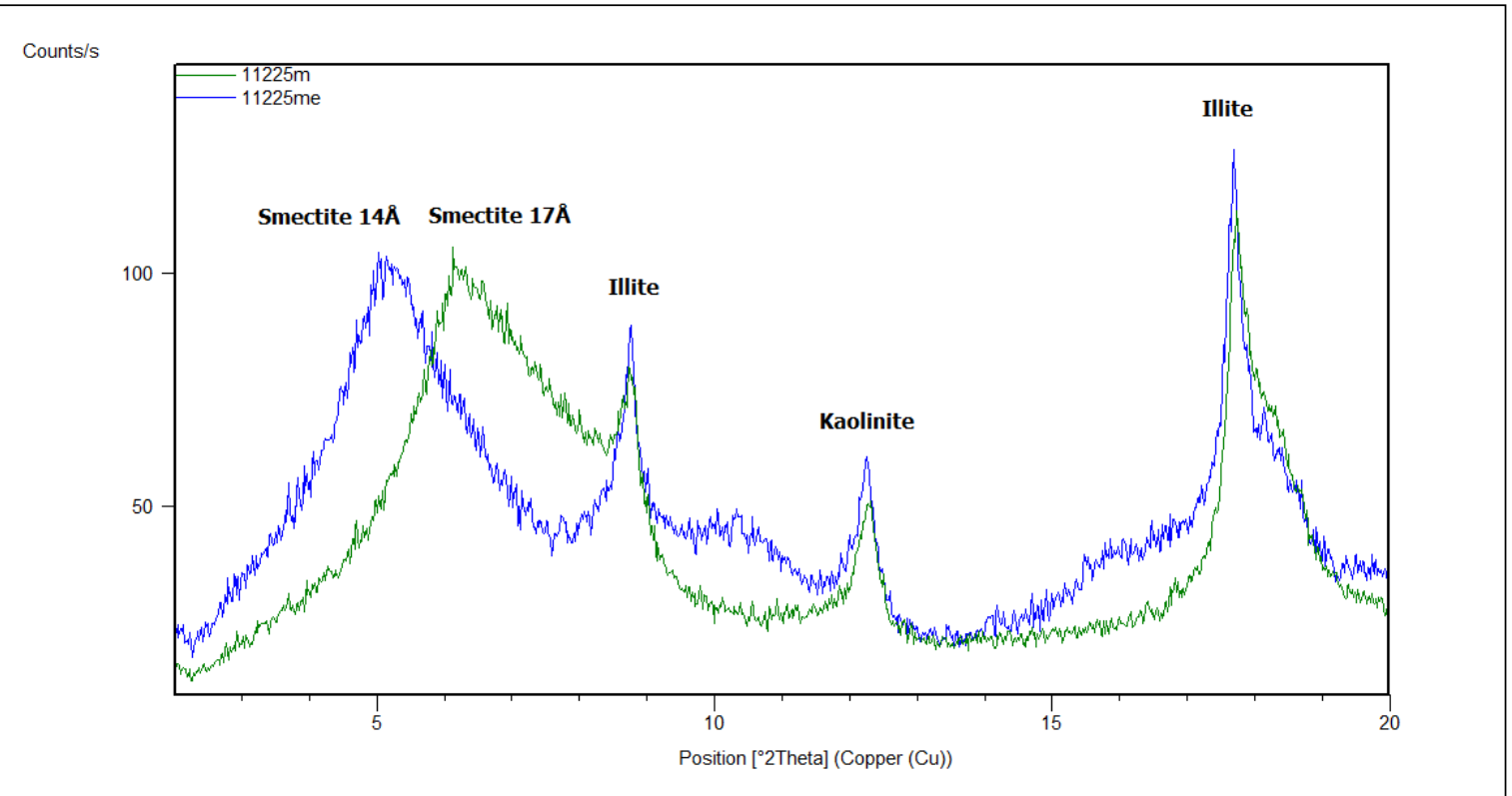

Fig. 4: X-ray diffractogram of the clay fraction $<2 \mu \mathrm{m}$ from OL2 Btg2 horizon. The green line is $\mathrm{Mg}$ treated and air dried, the blue line is Mgtreated and glycolated. The expansion of smectite from $14 \AA$ to $17 \AA$ is quite visible.

Abb. 4: Diffraktogramm der Tonfraktion <2 $\mu m$ aus dem Btg2 Horizont von OL2. Die grüne Kurve zeigt die Mg-behandelte und luftrockene Tonfraktion, die blaue Kurve die Mg-behandelte und glykolisierte Kurve. Deutlich ist die Aufweitung von Smektit von $14 \AA$ auf $17 \AA$ zu sehen.

are the clay illuvial Bt horizons of the Eemian paleosol OL2 and the basal gleyed paleosol OL5. We suppose that some strong chemical weathering processes should be taken into account when interpreting these maxima (CHAMLEY, 1989; SHELDON $\&$ TABOR, 2009). In the Eemian argic horizons the maximum of illuvial clay was registered by micromorphometric studies (Solleiro-Rebolledo et al., 2013). Furthermore, detailed micromorphological observations revealed abundant multiphase clay illuvial pedofeatures (SEDOV et al., 2013, this volume). We suppose that besides weathering, strong clay illuviation could contribute to the maximum of fine fractions observed in these horizons. This is confirmed by the abundance of fine clay and smectites, which are the most mobile components in suspensions. The lower paleosol unit OL5 represents a quite different soil environment. Both abundant morphological features of redoximorphic processes and minimal values of magnetic susceptibility point to water-logged anoxic conditions. Usually such conditions hamper silicate weathering. We should pay attention to the changes in the composition of parent material in this unit higher sand and lower silt content indicate an increase of the fluvial component. A part of the clay could be provided by slow fluvial sedimentation (overbank alluvium) being derived from the older pre-existing weathered materials of the Alpine Foreland.

In the Oberlaab sequence, grain size and mineralogical indicators of weathering provide more variable and sensitive signals of mineral transformations than the geochemical index CIA, presented by Solleiro-Rebolledo et al. (2013).

\section{References}

Ad-Hoc-Arbeitsgruppe Boden (2005): Bodenkundliche Kartieranleitung. - E. Schweizerbart'sche Verlagsbuchhandlung, Hannover.
Brindley, G.W. $\mho$ Brown, G. (1980): Crystal Structures of Clay Minerals and their X-Ray Identification. - Mineralogical Society, 495 pp., London.

Bronger, A. \& Heinkele, T. (1990): Mineralogical and clay mineralogical aspects of loess research. - Quaternary International 7/8, 37-51.

BRONGER, A., WinTER, R. \& SEDOv, S. (1998): Weathering and clay mineral formation in two Holocene soils and in buried paleosols in Tadjikistan: towards a Quaternary paleoclimatic record in Central Asia. - Catena 34: 19-34.

Buggle, B., Glaser, B., Hambach, U., Gerasimenko, N. ש Markovič, S.B. (2011): An evaluation of geochemical weathering indices in loess-paleosol studies. - Quaternary International 240, 12-21

Chamley, H., 1989: Clay Sedimentology. - Springer Verlag, 620 pp., Berlin.

Dixon, J.B. \& WEED, S.B. (eds.) (1989): Minerals in Soil Environments. - 2nd ed. Soil Science Society of America, Madison, WI. 1244 pp.

IUSS WorkING GROUP WRB, (2006): World Reference Base for Soil Resources. In: World Soil Resources Reports 103. FAO, Rome.

Moore, D.M. \& ReYnolds, R. C., JR. (1997): X - Ray Diffraction and the Identification and Analysis of Clay Minerals. - Oxford Univ. Press, 378 pp., New York.

Pécsi, M. ひ Richter, G. (1996): Löss Herkunft - Gliederung - Landschaften. - Zeitschrift für Geomorphologie N.F., Supplementband 98: $391 \mathrm{pp}$.

Scholger, R. \& Terhorst, B. (2013): Magnetic excursions recorded in the Middle toUpperPleistoceneloess/paleosol sequenceWels-Aschet(Austria). - E \& G Quaternary Science Journal 62 (1): 14-21, DOI: 10.3285/ eg.62.1.02

Sedov, S., Sycheva, S., PI, T. \& DíAz, J. (2013): Last Interglacial paleosols with argic horizons in Upper Austria and Central Russia: A comparative pedogenetic and paleoecological analysis. - E \& G Quaternary Science Journal 62 (1): 44-58, DOI: 10.3285/eg.62.1.05

SHELDON, N.D. $\mho$ TABOR, N.J. (2009): Quantitative paleoenvironmental and paleoclimatic reconstruction using paleosols. -Earth-Science Reviews, 95: 1-52.

Solleiro-Rebolledo, E., Cabadas, H., Sedov, S. \& Terhorst, B. (2013): Paleopedological record along the loess-paleosol sequence in Oberlaab Austria. - E \& G Quaternary Science Journal 62 (1): 22-33, DOI: 10.3285/eg.62.1.03

TERHORST, B. (2013): A stratigraphic concept for Middle Pleistocene Quaternary sequences in Upper Austria. - E \& G QuaternaryScience Journal 62 (1): 4-13, DOI: $10.3285 /$ eg.62.1.01

Terhorst, B., OtTner, F. \& Wriessnig, K. (2012): Weathering intensity and pedostratigraphy of the Middle to Upper Pleistocene loess/paleosol sequence of Wels-Aschet (Upper Austria). - Quaternary International 265: 142-154. 